\title{
NESTING BEHAVIOUR OF THE GREEN TURTLE AT KOSGODA ROOKERY, SRI LANKA
}

\author{
E.M.L. Ekanayake ${ }^{1,2,3}$, R.S. Rajakaruna ${ }^{1}$, T. Kapurusinghe ${ }^{3}$, M.M. Saman ${ }^{3}$, D.S. Rathnakumara ${ }^{3}$, \\ P. Samaraweera ${ }^{4}$ and K.B. Ranawana ${ }^{1}$ \\ ${ }^{1}$ Department of Zoology, Faculty of Science, University of Peradeniya, Peradeniya, Sri Lanka \\ ${ }^{2}$ Postgraduate Institute of Science, University of Peradeniya, Peradeniya, Sri Lanka \\ ${ }^{3}$ Turtle Conservation Project, No. 11, Perera Mawatha, Madakumbura, Panadura, Sri Lanka \\ ${ }^{4}$ Department of Molecular Biology and Biotechnology, University of Peradeniya, Sri Lanka \\ Accepted 19 December 2010
}

\begin{abstract}
Studies on nesting behaviour of turtles provide the most important information on their reproduction by providing estimates of female population size. Kosgoda, located in the southwest coast of Sri Lanka, has a year-round nesting rookery which is visited by five species of sea turtles, the green turtle being the most frequent visitor. Nesting behaviour of the female green turtle was studied at the Kosgoda rookery during a five-year period from August 2003 to July 2008. A total of 1,492 nests of the green turtle were recorded with a mean of 298.4 annual nests. Nesting took place year round, with $66 \%$ of nesting recorded during February to June. The highest and the lowest number of nests were recorded in April and November, respectively. The average clutch size of a female green turtle was 111.5 and the clutch frequency was 2.17. The average annual nesting abundance in the study area was 138.28. Of the 2,297 nesting attempts, 805 were false crawls accounting for a nesting success of $65 \%$. Females nesting at Kosgoda showed nest site fidelity. More than half of the females (54.3\%) nested in the same beach twice or more (mean 2.17) during the same nesting season. The highest number of re-nesting recorded was ten and the mean inter-nesting interval was 13.5 days. Of the 519 individuals tagged during the study period, 56 re-visited the same beach for nesting during the subsequent nesting seasons with a mean re-migration interval of 2.56 years. One female visited the same beach three times for nesting during the study period (after 2.67 years and then after 1.83 years). The nesting behaviour of the green turtle at Kosgoda rookery was similar to those at Rekawa, the largest rookery in Sri Lanka, located in the southern coast $130 \mathrm{~km}$ away from Kosgoda. Rekawa beach was declared a sea turtle sanctuary in 2006. This study shows that Kosgoda beach also provides a significant nesting site for the green turtle and highlights the need to declare it as a sanctuary.
\end{abstract}

Key words: clutch frequency, nesting success, re-nesting, re-migration, inter-nesting interval

\section{INTRODUCTION}

Of the seven species of sea turtles in the world, five species nest in the south and southwest coast of Sri Lanka. These include the green turtle, leatherback, olive ridley, hawksbill and the loggerhead turtle. Of them, the green turtle, Chelonia mydas (Linnaeus, 1758) is the most frequent visitor (Deraniyagala, 1939 \& 1953). The green turtle is a circum-global species and majority of its nesting and feeding grounds lie throughout the tropical (Prichard, 1997) and to a lesser extent in subtropical waters (Seminoff, 2004). Nesting occurs in more than 80 countries worldwide (Hirth, 1997). Their movements within the marine environment are less understood but it is believed that the green turtle inhabits coastal waters of over 140 countries (Groombridge and Luxmoore, 1989). Large nesting rookeries are found on mainland shores in Costa Rica (Bjorndal et al., 1999), barrier reef islands of Queensland, Australia (Limpus, 1995) and on Ascension Island (Godley et al., 2001). Some green turtle populations show year round nesting while others are seasonal nesters (Hirth, 1980).

The Green turtle produces multiple clutches of eggs per nesting season. The number of clutches laid by a female varies considerably from year to year and is dependent on dietary, behavioural and physiological factors (van Buskirk and Crowder, 1994; Miller et al., 2003). When a female selects a nesting beach, it has a tendency to re-nest in relatively close proximity $(0-5 \mathrm{~km})$ to the original nest during subsequent nesting attempts within a nesting season and

*Corresponding author's email: rupikar@pdn.ac.lk 
between nesting seasons. This behaviour is defined as the "nest site fidelity" (Miller, 1997). All sea turtles show nest site fidelity (Hirth, 1980; Ehrhart, 1992), among which the green turtle shows the highest degree of nest site fidelity (Miller, 1997; Bjorndal et al., 2005; Ekanayake et al., 2006; Formia et al., 2007).

A nesting female emerges from the ocean, crawls up the beach to find a suitable nesting site, and starts the nesting process. Turtles do not lay eggs during every nesting activity. They may abandon the nesting efforts at a number of different stages of the nesting process and return to the sea, which is called a false crawl (Miller, 1997). They usually emerge and nest later on the same or subsequent night. Close observations can assess whether or not an activity has resulted in the laying of a clutch (nest). A turtle may false crawl at any point in her nesting sequence up to the point where her eggs are laid. Nesting success is expressed as the proportion of activities which results in a nest.

Kosgoda rookery is the second largest turtle rookery in Sri Lanka, where year-round nesting of all five species of sea turtles take place. Clutch frequency, annual nesting abundance and nesting success are the most important parameters of turtle reproduction and are necessary to estimate female population size (Meylan, 1982). As the second largest rookery, Kosgoda provides an ideal location to study nesting behaviour of the female Green turtle. Although the reproductive behaviour of turtles nesting at Rekawa, the largest rookery in Sri Lanka, has been studied during the1990s (Kapurusinghe, 1996; Richardson, 1998) long term studies have not been carried out on nesting behaviour of the Green turtle at the Kosgoda rookery.

\section{MATERIALS AND METHODS}

\section{Study site}

One kilometre stretch of beach at Kosgoda $\left(6^{\circ} 33^{\prime} \mathrm{N}, 80^{\circ} 02^{\prime} \mathrm{E}\right)$ in the south-western coast of the island was selected for the study (Figure 1). Turtle rookery at Kosgoda covers a $4 \mathrm{~km}$ stretch of beach close to the Colombo - Galle main road, in a highly populated area (population at Kosgoda 7,500). The coastline presents a range of anthropogenic influence from urban to near wilderness areas. A large tourist hotel is located adjacent to the beach together with other developments and disturbances.

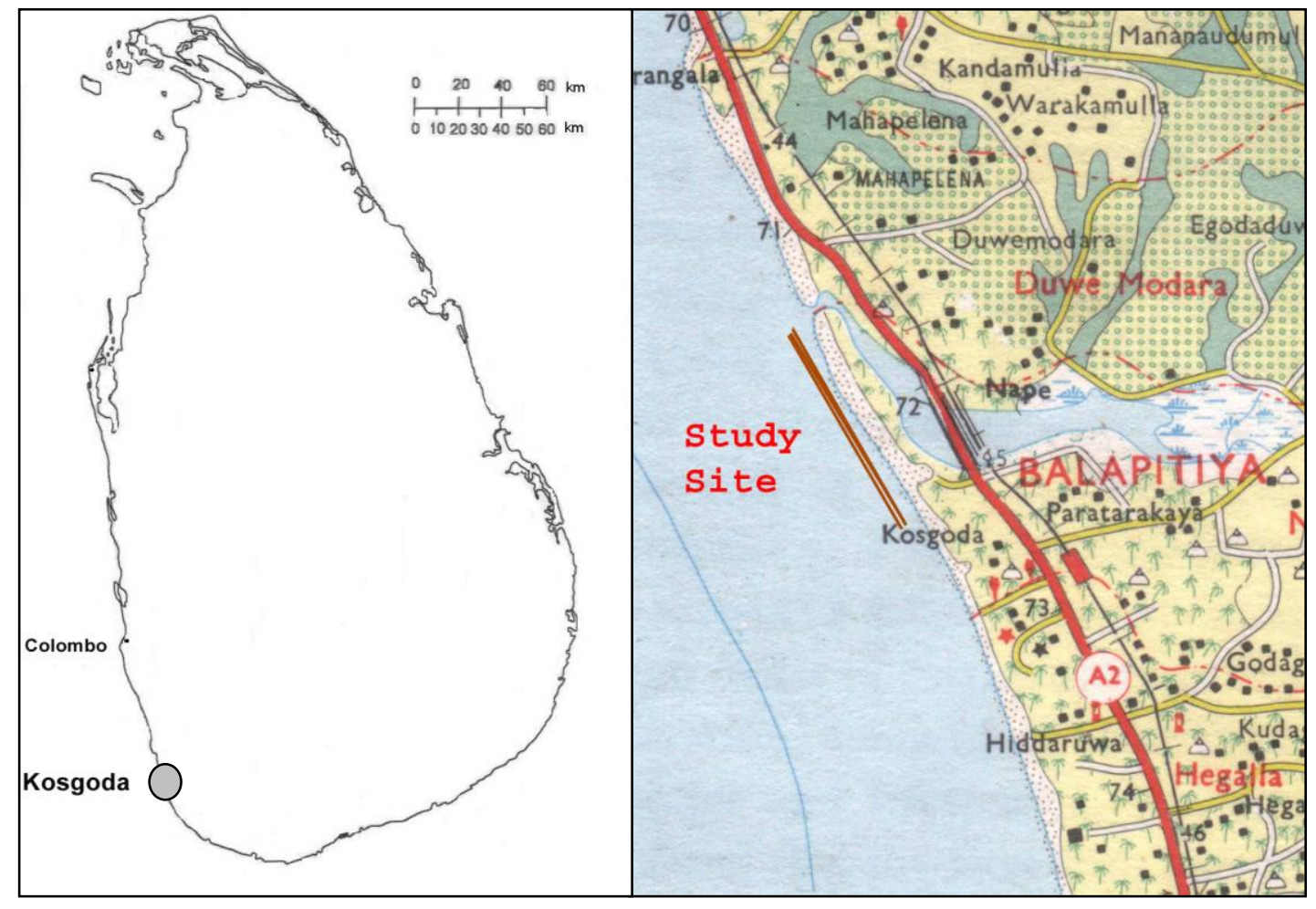

Figure 1. Map showing the study site at Kosgoda on the southwest coast of Sri Lanka. 
The beach access within the rookery operated area is limited, thereby creating a virtually undisturbed nesting and incubation area for the sea turtles. The coastline is characterized by natural vegetation, such as screw pine (Pandanus odoratissimus), half-flower tree (Scaevola taccada) and beach morning glory (Ipomea pes-caprae). Presence of predators of turtle eggs, such as dogs, lizards (Varanus salvator and Varanus bengalensis), mongoose (Herpestes sp.) and ghost crabs (Ocypode sp.) is common in and around the study site. Tidal amplitude is very low at Kosgoda. The slope of the beach is less than $30^{\circ}$ and most of the beach area consists of fine sand.

\section{Nesting activities}

The study area $(1 \mathrm{~km}$ stretch of beach at the Kosgoda rookery) was marked by wooden posts at $50 \mathrm{~m}$ intervals. The posts were consecutively numbered from 0 to 20 starting from the south end of the study area. Daily surveys of the green turtle nesting emergences were carried out from August 2003 to late July 2008 by the trained field assistants working in the Turtle Conservation Project (TCP). Beach was surveyed for $24 \mathrm{~h}$ for females emerging to lay eggs and the tracks were followed to determine whether a nest had been laid or the female had left the beach without nesting. The nesting area was monitored day and night to protect the nests from egg poachers and natural predators. The total number of nesters that laid eggs at the study site per year, clutch frequency (number of egg clutches deposited by a nesting female during a nesting season) and the annual nesting abundance (the total number of nests laid during a year/mean clutch frequency) were calculated.

\section{Nesting success}

The successful and abandoned nesting attempts (false crawls) were recorded. The percentage nesting success was calculated as a proportion of the total nesting attempts. Tracks were examined to determine the direction that the turtle was travelling which helped in identifying where she may have nested. The association between the number of successful nesting and number of false crawls was determined using Pearson's correlation.

\section{Nest site fidelity}

The nesting turtles were tagged on the front flipper when they were covering their egg chamber. Titanium tags (Stockbrands Co (Pvt.) Ltd., Western Australia) bearing an identification number and the address of the location (TCP, Sri Lanka) were used. Tagging of females was done only after nesting was completed. False crawlers were not tagged. Total number of new turtles (untagged) and the number of tagged females (re-nesting females and re-migrated females that had returned to Kosgoda after been tagged the previous season) were recorded. Even if the female turtle and nesting activity were not observed, new nests found on the beach were also identified and counted.

The inter-nesting interval of re-nesting turtles during a season was calculated by counting the days elapsed from its previous successful nesting date (for example if a tagged turtle nested on the $1^{\text {st }}, 12^{\text {th }}$ and the $30^{\text {th, }}$ her nesting intervals were calculated as 11 days and 18 days.). The remigration interval (inter-seasonal nesting periodicity) was calculated by counting the number of days from the last nest of the first season to the first nest of the next season.

\section{RESULTS}

\section{Nesting activities}

A total of 1,492 nests of the green turtle were recorded with mean annual nesting of 298.4 for the study period. The total number of nests per year varied during the five year study period, the highest number of 400 nests being recording in 2005-2006 and the lowest of 209 nests in 20062007 (Table 1). Year round nesting was observed with a distinct peak in April (Fig. 2) and the lowest in November. During the peak season (March to June) at least one or two females (daily mean 1.8) visited the beach daily, the highest being 7 nesters. The highest number of monthly nesting was observed in March 2006 (63 nests) while the lowest was recorded for January and October 2007 (three nests each; Fig. 3).

The mean clutch frequency (number of egg clutches deposited by a nesting female during a nesting season) was 2.17 and the annual nesting abundance varied from 110.00 to 171.67 per year, highest being recorded during 2005 - 2006 (Table 1). The minimum number of eggs laid by the green turtle was four which was recorded from a disturbed female. She never returned to nest at the same site. The maximum number of eggs laid by a female was 1,249 which were laid in nine nests in one season in 2007/2008. Same female (tag numbers: Left flipper 2719/ Right flipper 2751) laid 708 eggs in six nests during her previous nesting season in 2005/2006. 
Table 1. Number of nests and eggs, clutch frequency and nesting abundance of the green turtle at Kosgoda turtle rookery during the five-year study period.

\begin{tabular}{cccccc}
\hline Year & No. of nests & No. of eggs & \multicolumn{2}{c}{ Clutch frequency } & Annual nesting \\
\cline { 4 - 5 } abundance
\end{tabular}

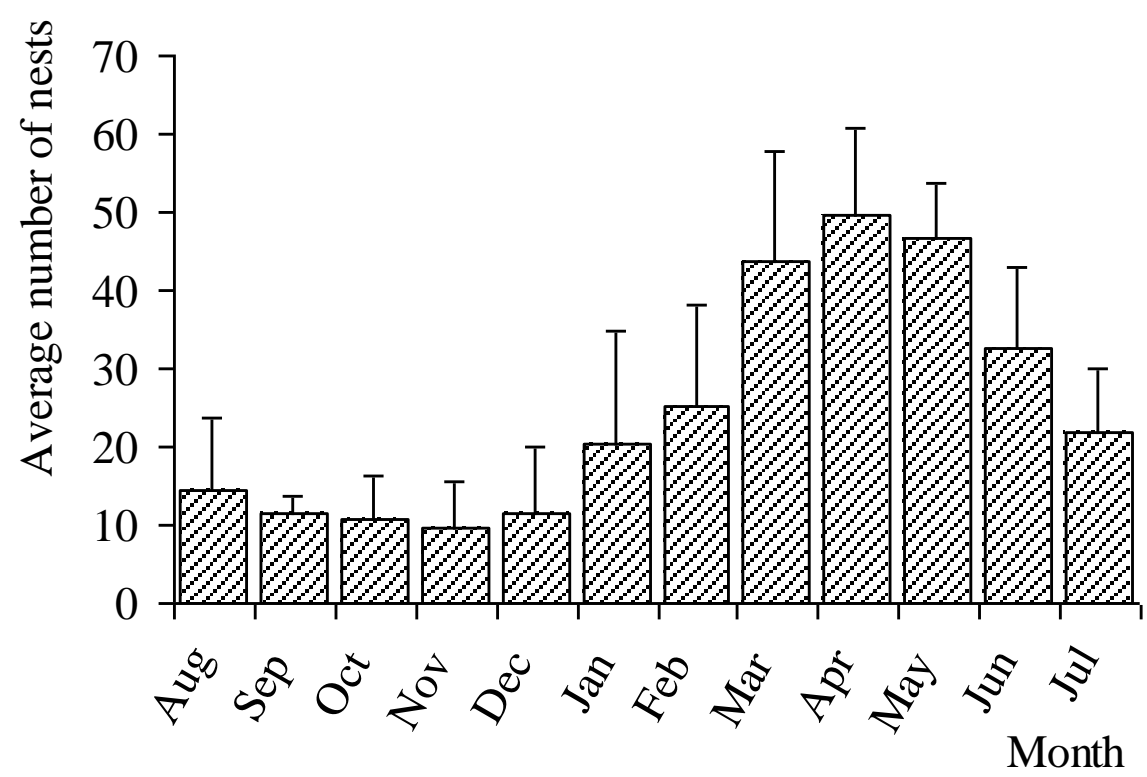

Figure 2. Number of nests of the green turtle recorded in each month at the Kosgoda rookery during the five-year study period. 

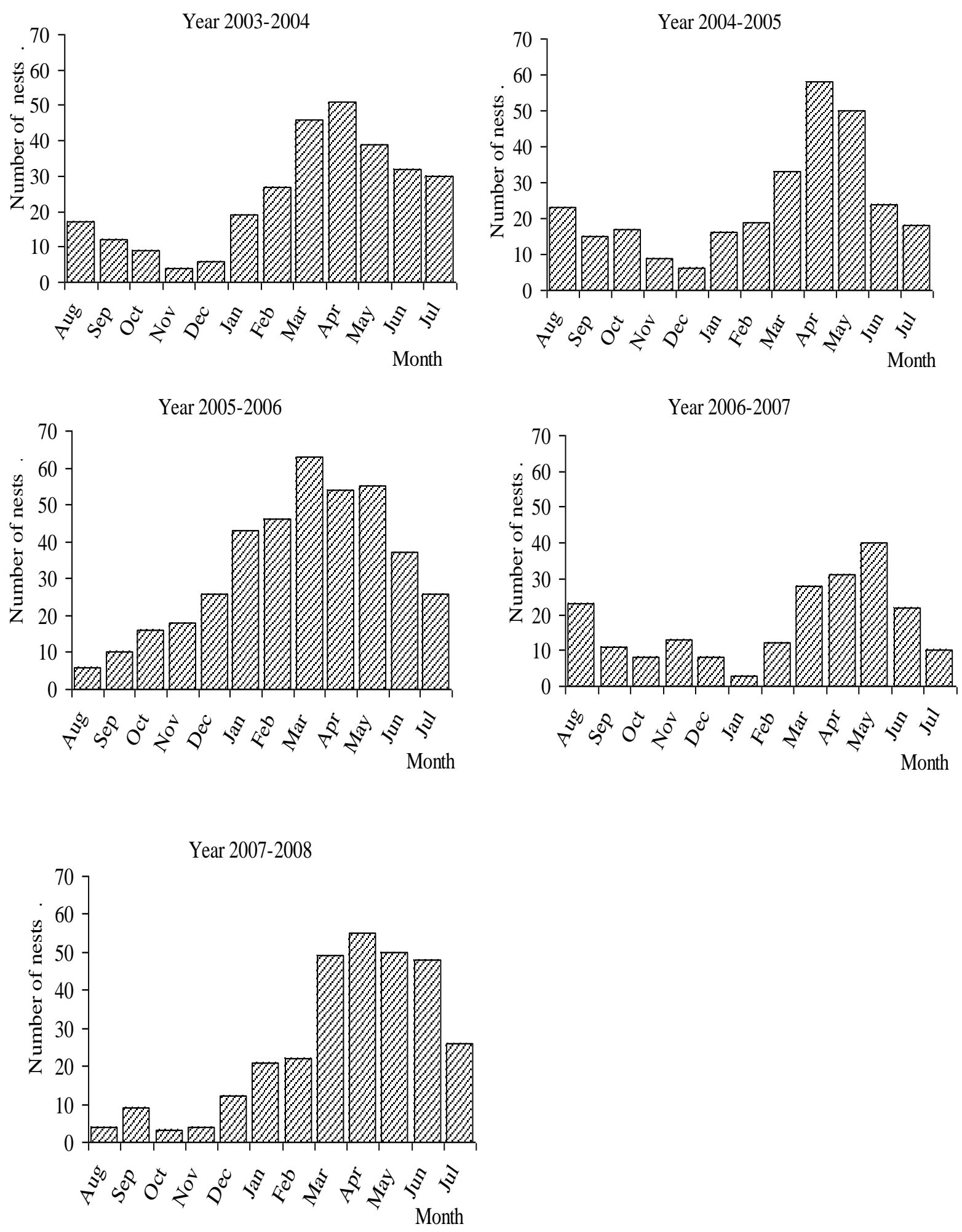

Figure 3. Pattern of monthly nesting frequency of the green turtle at Kosgoda rookery during the five-year study period. 


\section{Nesting success}

Of a total of 2,297 nesting attempts recorded during the 5-year study period, 805 were false crawls (35\%). Therefore, the nesting success at the Kosgoda beach during the study period was $65 \%$. There was a significant increase in the number of false crawls with increasing number of nests (Fig. 4; Pearson's Correlation $\mathrm{r}=0.388$; $\mathrm{p}<0.01)$.

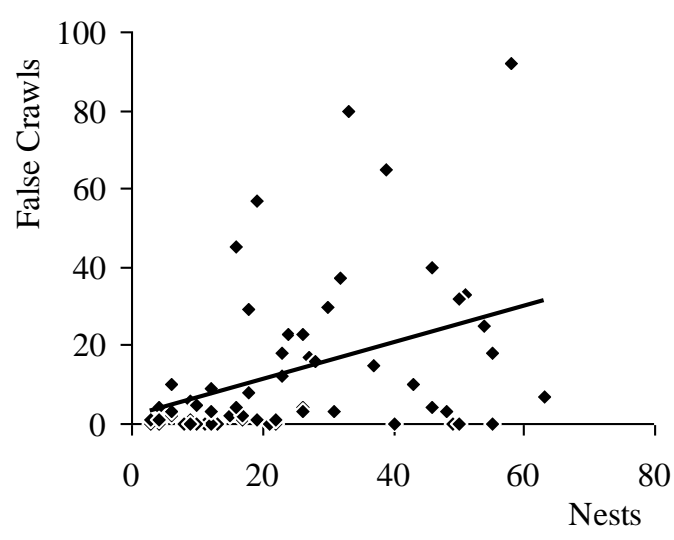

Figure 4. Relationship between number of false crawls and number of nests of the green turtle at Kosgoda rookery from 2003 to 2008 (Pearson's Correlation $r=0.388 ; p<0.01$ ).

\section{Re-nesting, re-migration and nest site fidelity} Re-nesting and re-nesting interval

More than half of the females $(54.3 \%)$ nested twice or more while some females $(45.3 \%)$ nested only once during the same nesting season. The clutch frequency (number of nests laid by a female during a single nesting season) is shown in Fig. 5. The average number of re-nesting recorded for the study period was 2.17 with the highest number being 10 . The inter-nesting interval for the green turtle varied from 7 - 43 days with a mean inter-nesting interval of 13.5 days (Table 2) for the study period. The distribution peaked at $10-15$ days (Fig. 6).

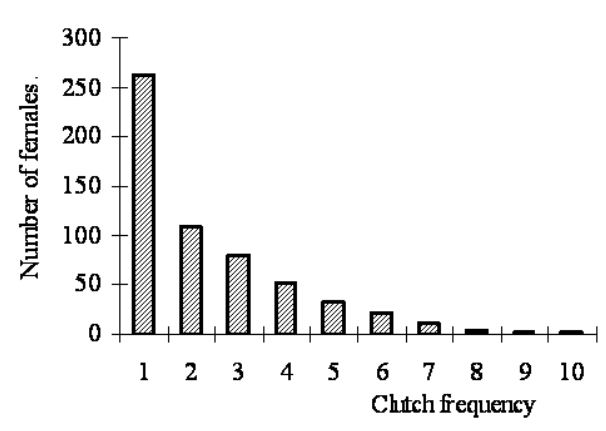

Figure 5. Clutch frequency of the green turtle at Kosgoda rookery recorded during the 5year study period

Re-migration and re-migration interval

Of the 519 individual green turtles tagged (Table 2), 56 visited the same beach again for nesting in the following seasons. The mean remigration interval was $2.56( \pm 0.58)$ years (Fig. 2 ). Only one turtle visited the study area for three consecutive seasons for nesting during the study period (initially after 2.67 years and then after 1.83 years). Two clear peaks at 2 and 3 years were observed in their re-migration pattern (Fig. 7).

Table 2. Number of tagged nesters, inter-nesting interval, number that visited the next season and the re-migration interval of the green turtle at Kosgoda rookery during the 5-year study period

\begin{tabular}{cccccc}
\multirow{2}{*}{ Year } & $\begin{array}{c}\text { Number of } \\
\text { nesters } \\
\text { tagged }\end{array}$ & \multicolumn{2}{c}{ Inter nesting interval/days } & $\begin{array}{c}\text { No. visited } \\
\text { next season }\end{array}$ & $\begin{array}{c}\text { Re-migration } \\
\text { interval/years }\end{array}$ \\
\cline { 3 - 4 } & 108 & $13.04( \pm 3.44)$ & $8-35$ & 19 & 2.74 \\
\hline $2003-2004$ & 113 & $13.45( \pm 4.26)$ & $8-31$ & 26 & 2.75 \\
$2004-2005$ & 138 & $13.02( \pm 3.12)$ & $8-25$ & 10 & 1.89 \\
$2005-2006$ & 61 & $15.32( \pm 6.53)$ & $7-43$ & 1 & 1.42 \\
$2006-2007$ & 99 & $13.75( \pm 4.37)$ & $8-32$ & N/A & N/A \\
$2007-2008$ & 519 & $13.5( \pm 4.18)$ & $7-43$ & 56 & 2.56 \\
\hline Total & & & & &
\end{tabular}




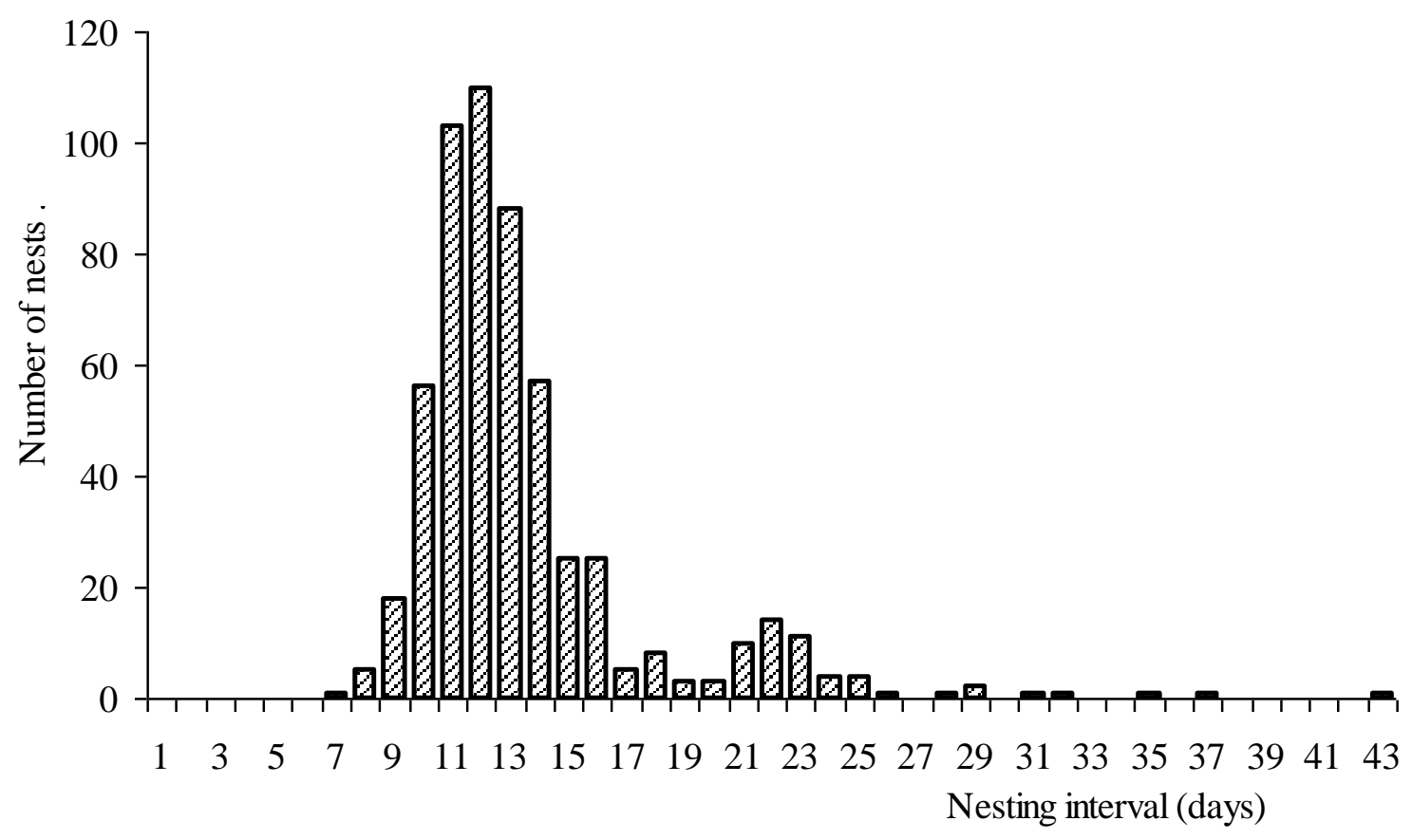

Figure 6. Inter nesting interval of the green turtle at Kosgoda rookery from 2003 to 2008.

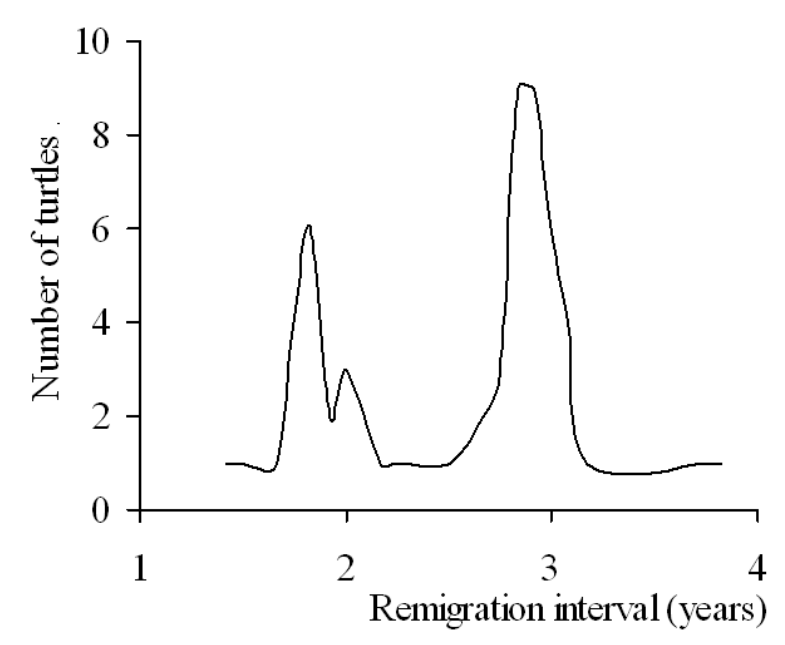

Figure 7. Re-migration interval of the female green turtle at Kosgoda rookery from 2003 to 2008.

\section{DISCUSSION}

Nesting activities of the green turtle took place throughout the year at Kosgoda rookery with $66 \%$ of nesting occurring during February to June. They mainly nested during the dry, warm season. Nesting populations of the green turtle at Rekawa also showed a similar pattern of year-round nesting, with peaks during February and June (Ekanayake et al., 2002). At Kosgoda rookery the highest number of nesting was observed in April and the lowest in November which is similar to the nesting pattern at Rekawa rookery (Ekanayake et al., 2002). A similar nesting pattern has been observed in the green turtle populations nesting in Mayotte Island, South West Indian Ocean (Bourjea, et al., 2007), Grande Glorieuse Island, South West Indian Ocean (Lauret-Stepler et al., 2007) and Huyong Island, Thailand (Yasuda et al., 2006), with peaks during February to June and nesting throughout the year. However, in certain countries such as Pakistan (Qureshi, 2006), Europa, Tromelin Islands, South West Indian 
Ocean (Lauret-Stepler et al., 2007) and Derawan Island complex, Indonesia (Adnyana et al., 2008), different nesting peaks have been observed with year-around nesting. Nesting is seasonal in some regions, lasting only during part of the year with the duration ranging from 2-3 months or up to 5- 6 months. Such seasonal nesting has been observed in Andaman Islands (Harry et al., 2006) Tortuguero, Costa Rica (Fowler, 1979; Hirth, 1980; Trong and Rankin, 2005; Trong and Chaloupka, 2007), Surinam (Hirth, 1980) and Caymen islands (Aiken et al., 2001). Nesting usually occurs in the warmest months and even in the few populations that nest year-round, there is a marked annual peak (Miller, 1997). The green turtle has evolved to nest during periods of the year when the sand temperatures are highest, avoiding the months when nest temperatures may get too low (Goodley et al., 2001; 2002). Seasonal nesting is presumably a result of females timing their reproductive activity to coincide with climatic conditions that are most conducive to maximizing reproductive fitness.

The average annual nesting at Kosgoda rookery was 332 nests per kilometre. The Rekawa rookery, the major turtle nesting site in Sri Lanka, has a much higher average annual nesting of 416 per kilometre ((Ekanayake et al., 2002). Even though Kosgoda rookery has fewer nesting than Rekawa and other nesting beaches around the world, it is considered a significant nesting beach in the Indian sub-continent.

The number of clutches laid in a season by female turtles varied with the species, population and different individuals. Carr (1952) stated that the green turtle lay two to five times in a single nesting season and another study recorded that one green turtle laid 12 nests during a single nesting season in Redang Island, east coast peninsula in Malaysia (Chan, Personal communication). Clutch frequency varied from 1 - 10 with a mean of 2.17 at Kosgoda rookery. Ekanayake et al. (2002) reported a higher mean clutch frequency of 4.0 (range 1-12) at Rekawa rookery. Varying clutch frequencies of 1.8, 2.9, 4.1 and 5.5 in French Frigate Shoals- Hawaii, Surinam, Sarawak Islands and Heron IslandsAustralia, respectively among different green turtle populations around the world have been reported (Hirth, 1997). More recent studies show similar clutch frequencies of 3.0 in Mayotte Island (Bourjea, et al., 2007) and 2.93 in British Virgin Islands (McGowan et al., 2008). Laying several clutches during a single nesting season helps to reduce egg loss by unpredictable environmental changes (Miller, 1997). Moreover, by placing a number distinct size classes of offsprings with different sizes or hatchling dates may have survival advantages. Increase in clutch size with increasing latitude has been reported in a number of North American turtles (Congdon and Gibbons, 1985; Iverson, 1992; Iverson et al., 1993; 1997). In lower latitudes, smaller multiple clutches would have a significant survival advantage. For temperate species, early hatching would allow hatchlings to grow prior to hibernation and late hatchlings to possibly get through their first winter on food reserves from absorbed yolks. More importantly, clutches deposited over time would decrease the likelihood that the total reproductive output of a single individual would be consumed by a nest predator (Obbard and Brooks, 1981). Thus, multiple clutching may be more important for long-term survival of populations than total reproductive output.

Sixty five percent of the nesting attempts at Kosgoda rookery during the study period were successful while the rest $(35 \%)$ were false crawls. In comparison, at Rekawa, $53 \%$ of the green turtle nesting attempts were successful, while the percentage of false crawls was higher, 47\% (Ekanayake, 2003). Similar, nesting successes of $63.5 \%, 45 \%$ and $50 \%$ of the green turtle have been reported in Tortuguero in Costa Rica (de Haro et al., 2006), Dry Tortugas National Park in West Florida (Reardon, 2000) and at East-Central Florida beach (Weishampel et al., 2003), respectively. Some of the observed reasons for the false crawls are disturbances due to artificial lights, people walking in front of emerging turtles, disturbance by dogs, noise or other unusual activities in beaches, encountering obstacles while crawling up the beach or while digging egg chambers, the sand not having the right consistency or moisture or other unknown reasons. A turtle may even complete her egg chamber and for some reason not deposit her eggs. Having analysed physical and chemical characteristics of beach sand from fifty nesting areas around the world, Mortimer (1990) concluded that physiognomy of sand in nesting beaches may be a more important reason for abandoning a nesting attempt than the other factors. It is also believed that turtles select a well-ventilated substrate (Ackerman, 1980) with low salinity and high humidity (Miller, 1997). However, for most of the false crawls the reason remains unknown.

Green turtles show a high degree of nest site fidelity (Miller, 1997; Bjorndal et al., 2005; 
Ekanayake et al., 2006; Formia et al., 2007). Results of the present study also show nest site fidelity of the green turtle nesting at Kosgoda rookery. A total of 234 females $(54.3 \%)$ visited the same stretch of Kosgoda beach for re-nesting in a single nesting season during the study period. However, a much higher re-nesting frequency of $78.9 \%$ has been reported from Rekawa (Ekanayake et al., 2004). The lower frequency of re-nesting at Kosgoda may be due to the short stretch of beach $(1 \mathrm{~km})$ therein, compared to $2 \mathrm{~km}$ in Rekawa. Usually there is a tendency for a female to re-nest in relatively close proximity (ranging from $0-5 \mathrm{~km}$ ) to the original nest during subsequent nesting attempts within a nesting season and between nesting seasons (Miller, 1997). Had a longer stretch been selected as the study area, a higher frequency of re-nesting could be expected.

The mean inter-nesting period for green turtles nesting at Kosgoda rookery was 13.5 days (range 7- 43 days). A similar inter-nesting interval of 13.6 days has been reported for green turtles nesting at Rekawa (TCP, unpublished data). The inter-nesting interval ranged from 1014 days in green turtle populations around the world (Miller, 1997; Aiken et al., 2001). The inter-nesting period of the Tortuguero green turtles was 8 to 33 days (Troeng and Rankin, 2005). During the inter-nesting period, female turtles mainly rest and they may feed only if there are foraging grounds close to the nesting beach (Hays et al., 1999; 2002). When a female turtle arrives at a nesting area she carries a full set of follicles to supply yolk for all the eggs she will lay during the season (Miller, 1997). From the time follicles ovulate from the ovary, it will take a minimum of seven days to complete shell formation (Miller, 1985) and hence, a minimum of seven days of inter-nesting duration is required.

Generally, female sea turtles do not reproduce every year. The duration between two reproductive seasons varies among species, and the re-migration interval varies from 1-7 years or more (Hirth, 1980; Miller, 1997). Mean remigration interval for the green turtle at Kosgoda was 2.56 years with one female visiting the Kosgoda beach, in three consecutive seasons for nesting during the five year study period. This was the highest number of turtle re-migrations recorded from Sri Lanka, so far. In Rekawa, a re-migration interval of 2.5 - 3.5 years has been reported for the green turtle (Ekanayake and Ranawana, 2004). Similar re-migration intervals of 2-3 years have been reported for the green turtles in Tortuguero, Costa Rica (Trong and Chaloupka, 2007), Mayotte Island (Bourjea, et al., 2007), Cyprus (Broderick, et al., 2003) and Ascension Island (Broderick et al., 2006). The re-migration interval of turtles depends on the periods of extensive food supply, during which the turtles accumulate fat reserves. It also depends on the time taken to complete vitellogenesis and time taken to travel the distance between feeding site and nesting beach. When the sea turtles reach reproductive readiness, males and females begin to migrate from their feeding grounds to copulate at breeding areas found in the region of the nesting sites (Hirth, 1997). A female that was tagged at Kosgoda on May16, 2008 had been recovered from the beach of Phang-nga Province, the north of Phuket, Thailand on July 14, 2009 (Ekanayake et al., 2010). Even though tags of remigrating females have been recovered along the coasts of Sri Lanka many times (TCP, Unpublished data), this was the first time that tag recoveries were reported outside the island with a travel distance of more than $2000 \mathrm{~km}$. This is also the longest track that a green turtle had migrated, to be reported from Sri Lanka. However, as the turtle was found dead on the beach, the exact location of its feeding ground is unknown. It could be a place close to Andaman Islands or Thailand. Female green turtles tagged using satellite tags in Rekawa turtle rookery in southern coast of Sri Lanka have travelled to the Gulf of Mannar Biosphere Reserve, off Tamil $\mathrm{Nadu}$, India, (a distance of about $410 \mathrm{~km}$ ) and to the coast of Karnataka, Western India, travelling a distance of about $1,130 \mathrm{~km}$ (Richardson et al., 2010). The green turtles nesting in Kosgoda and Rekawa may be different populations with different feeding as well as breeding grounds. A satellite tagging of the turtle populations in the Kosgoda rookery is required to confirm the migratory patterns of the green turtle. Global conservation efforts for sea turtles are focused on nesting and foraging areas as well as the their migratory pathways. This study provides evidence that females of the green turtles nesting in Sri Lankan beaches do migrate outside the coastal waters of Sri Lanka and highlights the importance of incorporating regional coordination as recommended in the Marine Turtle Action Plan of Sri Lanka.

Understanding the behaviour of nesting populations at a rookery is important for longterm monitoring of life history traits of the green turtle to provide a meaningful insight into their conservation. The Rekawa beach was declared as Sri Lanka's first marine turtle sanctuary by 
the Department of Wildlife Conservation, in 2006. The present study shows that Kosgoda rookery is also an important nesting beach for the green turtle and highlights the significance of declaring it a sanctuary.

\section{ACKNOWLEDGEMENTS}

Authors thank the staff of the Turtle Conservation Project (TCP) for their technical support and Department of Wildlife Conservation for granting permission to carry out this study. National Science Foundation (NSF) Sri Lanka, through grant number SIDA/2005/B7/01 and UNDP-GEF/SGP small grant programme are acknowledged for financial support.

\section{REFERENCES}

Adnyana, W.L.P., Soede, G., Gearheart, M. and Halim, M. (2008). Status of the green turtle (Chelonia mydas) nesting and foraging populations of Berau, East Kalimantan, Indonesia, including results from tagging and telemetry. Indian Ocean Turtle Newsletter 7: 211 .

Aiken, J.J., Godley, B.J., Broderick, A.C., Austin, T.J., Ebanks-Petrie, G. and Hays, G.C. (2001). Two hundred years after a commercial marine turtle fishery: the current status of marine turtles nesting in the Cayman Islands. Oryx 35: 145-151.

Ackerman, R.A. (1980). Physiological and ecological aspects of gas exchange by marine turtle eggs. American Zoologist 20: 575-583.

Bjorndal, K.A., Bolten, A.B. and Troe"ng, S. (2005). Population structure and genetic diversity in green turtles nesting at Tortuguero, Costa Rica, based on mitochondrial DNA control region sequences. Marine Biology 147: 1449-1457.

Bjorndal, K.A., Wetherall, J.A., Bolton, A.B. and Mortimer, J.A. (1999). Twenty -six years of green turtle nesting at Tortuguero, Costa Rica: an encouraging trend. Conservation Biology 13: 126-134.

Bourjea, J., Frappier, J., Quillard, M., Ciccione, S., Roos, D., Hughes, G. and Grizel, H. (2007). Mayotte Island: another important green turtle nesting site in the southwest Indian Ocean. Endangered Species Research 3, 273-282.

Broderick, A.C., Glen, F., Godley, B.J. and Hays, G.C. (2003). Variation in reproductive output of marine turtles. Journal of Experimental Marine Biology and Ecology 288: 95-109.

Broderick, A.C., Frauenstein, R., Glen, F., Hays,G.C., Jackson, A.L., Pelembe, T., Ruxton, G.D. and Godley, B.J. (2006). Are green turtles globally endangered? Global Ecology and Biogeography 15: 21-26.

Carr, A. (1952). Handbook of turtles, the Turtles of the United States, Canada, and Baja California, Cornell University Press, Ithaca, New York., 341-460.

Congdon, J.D. and Gibbons J.W. (1985). Egg components and reproductive characteristics of turtles: relationships to body size. Herpitologica 41:194-205.

De Haro, A., Troëng, S., Abad, A., Becker, R., Contreras, M., Huertas, V., Kennealy, S., Lawrence, R., Macdonald, E., Monroy, Y., Morales, R., Norwood, A., Pajuelo, M., Palomares, I., Paz, A., Peñalver, O., Rodríguez, M., Quan, J., Tugrí, A., Tugrí, J. and Vargas, E. (2006). Report on the 2005 Green Turtle Program at Tortuguero, Costa Rica.

Deraniyagala, P.E.P. (1939). The Tetrapod reptiles of Ceylon. Testudinates and Crocodilians, The Director, Colombo Museum; London, Dulau and Co., Ltd. 1: 412

Deraniyagala, P.E.P. (1953). A coloured atlas of some vertebrates from Ceylon. Tetrapod Reptiles, Colombo Museum, Colombo, Sri Lanka. 2:101.

Ehrhart, L.M. (1992). Turtles of the worm-rock reefs. Florida Naturalist 65: 9-11.

Ekanayake, E.M.L., Kapurusinghe, T., Saman, M.M., Rathnakumara, A.M.D.S., Rajakaruna, R.S., Samaraweera, P. and Ranawana, K.B. (2010). Re-nesting movements and post-nesting migrations of green turtles tagged in two turtle rookeries in Sri Lanka. Proceedings of the $30^{\text {th }}$ Annual Symposium on Sea Turtle Biology and Conservation, Goa, India.

Ekanayake, E.M.L., Ranawana K.B. and Kapurusinghe, T. (2006). Nest Site Fidelity of Green Turtles in the Rekawa Turtle Rookery in Sri Lanka. Proceedings of the $23^{\text {rd }}$ Annual 
Symposium on Sea Turtle Biology and Conservation. NOAA Technical Memorandum NMFS-SEFSC 536: 7-9.

Ekanayake, E.M.L., Ranawana, K.B., Kapurusinghe, T., Premakumara, M.G.C. and Saman, M.M. (2002). Marine Turtle Conservation in Rekawa Turtle Rookery in Southern Sri Lanka. Ceylon Journal of Science (Biological Science) 30: 79-88.

Ekanayake, E.M.L., Ranawana, K.B. and Kapurusinghe, T. (2004). Estimation of the average number of nests for green turtle, on the Rekawa beach in Southern Sri Lanka. Threeyear study from September 1996 to September 1999. Proceedings of the $21^{\text {st }}$ Annual Symposium on Sea Turtle Biology and Conservation, NOAA Technical Memorandum NMSF-SEFSC-528: 160-161.

Ekanayake, E.M.L. and Ranawana, K.B. (2004). The average egg count for nesting sea turtles on Rekawa beach in Sri Lanka. Lyriocephalus 5: 32-34.

Ekanayake, E.M.L. (2003). Nest site fidelity and nesting behaviour of marine turtles in Rekawa turtle Rookery. M.Phil. Thesis, Postgraduate Institute of Science (PGIS), University of Peradeniya, Sri Lanka.

Formia, A., Broderick, A.C., Glen, F., Godley, B.J., Hays, G.C. and Bruford, M.W. (2007). Genetic composition of the Ascension Island green turtle rookery based on mitochondrial DNA; implications for sampling and diversity. Endangered Species Research 3: 145-158.

Fowler, L.E. (1979). Hatching success and nest predation in the green sea turtle, Chelonia mydas, at Toxtuguem, Costa Rica. Ecology 60: 946-955.

Godley, B. J., Broderick, A.C., Frauenstein, R., Glen, F., and Hays, G.C. (2002). Reproductive seasonality and sexual dimorphism in green turtles. Marine Ecological Progress Series 226: 125-133.

Godley, B. J., Broderick, A. C. and Hays, G. C. (2001). Nesting of green turtles Chelonia mydas at Ascension Island, South Atlantic. Biological Conservation 97: 151-158.

Groombridge, B., and Luxmoore, R. (1989). The Green Turtle and Hawksbill (Reptilia: Cheloniidae): World Status, Exploitation and
Trade. Lausanne, Switzerland: CITES Secretariat, pp 601.

Harry, V.A., Krishnan, S. and Biwash, P. (2006). Distribution and status of marine turles in the Andaman and Nicobar Islands. In: K. Shanker and B.C. Choudry (Eds) Marine Turtles of the Indian Subcontinent. Universities Press (India) Private Limited. 38-58.

Hays, G.C., Puschi P., Papi F., del Seppia C., and Marsh, R. (1999). Changes in behaviour Herpetology Monographs 6: 25 -42.

Hays, G.C., Broderick, A.C., Glen, F. and Godley B.J. (2002) Change in body mass associated with long-term fasting in a marine reptile: the case of green turtles (Chelonia mydas) at Ascension Island. Canadian Journal of Zoology 80: 1299-1302

Hirth, H.F. (1980).Some aspects of the nesting behaviour and reproductive biology of marine turtles. American Zoologist 20: 507-523.

Hirth, H.F. (1997). Synopsis of biological data on the green turtle Chelonia mydas (Linnaeus 1758). U.S. Fish and Wildlife Service. Biological Report 97:1-120.

Iverson, J.B., Higgins, H., Sirulnik A. and Griffiths, C. (1997). Local and geographic variation in the reproductive biology of the snapping turtle (Chelydraserpentina). Herpetologica 53: 96-117.

Iverson, J.B., Balgooyecn. P., Byrdk, K. and Lyddank, K. (1993). Latitudinal variation in egg and clutch size in turtles. Canadian Journal of Zoology 71: 2448-2461.

Iverson, J.B. (1992). Correlates of reproductive output in turtles (Order Testudines). Herpetology Monographs 6: 25 -42.

Kapurusinghe, T. (1996). The decline of nesting turtle populations in Rekawa, Sri Lanka. International Conference on the Biology \& Conservation of the Amphibians \& Reptiles of South Asia. Amphibia and Reptile Research Organization of Sri Lanka. Pp. 22.

Lauret-Stepler, M., Bourjea, J., Roos, D., Pelletier, D., Ryan, PG., Ciccione, S. and Grizel, H. (2007). Reproductive seasonality and trend of Chelonia mydas in the south-western Indian Ocean, a 20 year study based on track counts. Endangered Species Research 3: 217-227. 
Limpus, C.J. (1995). Global overview of the status of marine turtles: a 1995 review. In: K.A. Bjorndal (Ed), Biology and conservation of sea turtles. Smithsonian Inst. press, Washington D.C. 605-609.

McGowan, A., Broderick, A.C., Frett, G., Gore, S., Hastings, M., Pickering, A., Wheatley, D., White, J., Witt, M.J. and Godley, B.J. (2008). Down but not out: marine turtles of the British Virgin Islands. Animal Conservation 11: 92-103.

Meylan, A. (1982). Sea turtle migration evidence from tag returns. In: K.A. Bjorndal (Ed), Biology and Conservation of Sea Turtles. Smithson. Inst. Press, Washington, DC: 91-100.

Miller, J. D. (1985). Embryology of marine turtles. In: C. Gans, F. Billett, and P.F.A. Maderson (Eds) Biology of the Reptilia. New York: Wiley-Interscience.14A: 269-328.

Miller, J.D. (1997). Reproduction in Marine turtles. In: P.L. Lutz and J.A. Musick (Eds) The biology of marine turtles.. CRC Press, Washington DC., 51-81.

Miller, J.D., Limpus, C.J., and Godfrey, M.H. (2003). Nest site selection, oviposition, eggs, development, hatching, and emergence of loggerhead turtles. In: A. Bolten and B. Witherington (Eds), Biology and Conservation of Loggerhead Sea Turtles. University of Washington Press, 125-143.

Mortimer J.A. (1990). The influence of beacth sand characteristics on the nesting-behaviour and clutch survival of green turtles (Chelonia mydas) Copeia 1990(3): 802-917

Obbard, M. E., and Brooks, R.J. (1981). A radiotelem- etry and mark-recapture study of the activity in the common snapping turtle, Chelydra serpentina. Copeia 1981(3): 630-637.

Prichard, P.C.H. (1997). Evolution, Phylogeny, and Current Status., In: P. L. Lutz and J.A. Musick (Eds), The Biology of sea turtles, CRC Press, Washington DC.1-28.

Qureshi, M.T. (2006). Sea turtles of Pakistan. In: K. Shanker and B.C. Choudry (Eds), Marine Turtles of the Indian Subcontinent. Universities Press (India) Private Limited. 217-224.
Reardon R.T. (2000). Annual report - 2000 season. Dry Tortugas National Park Sea Turtle monitoring program. Dry Tortugas, Florida. Pp.49.

Richardson, P.B., Broderick, A.C. Coyne, M.S., Ekanayake, E.M.L., Kapurusinghe, T., Premakumara, C., Rathnayake, W., Saman, M.M., Matthew, J., Witt, J. and Godley B.J. (2010). Satellite tracking suggests size-related differences in behaviour and range of female green turtles nesting at Rekawa wildlife sanctuary, Sri Lanka. Proceedings of the $30^{\text {th }}$ Annual Symposium on Sea Turtle Biology and Conservation, Goa, India.

Richardson, P. (1998). An update of the progress of the Turtle Conservation Project (TCP), Sri Lanka. Testudo 4: 64-70

Seminoff, J. (2004). Green Turtle Red List Assessment.< http://www.iucn-mtsg.org>. IUCN Species Survival Commission.

Trong, S. and Chaloupka, M. (2007). Variation in adult annual survival probability and remigration intervals of sea turtle. Marine Biology 151: 1721-1730.

Troneng, S and Rankin, E. (2005). Long-term conservation efforts contribute to positive green turtle Chelonia mydus nesting trend at Tortuguero, Costa Rica. Biological Conservation 121: 111-116.

Van Buskirk, J., and Crowder, L.B. (1994). Life-history variation in marine turtles. Copeia, 1994 (1): 66-81.

Weishampel, J.F., Bagley, D.A., Ehrhart, L.M., Rodenbeck. B.L. (2003). Spatiotemporal patterns of annual sea turtle nesting behaviors along an East Central Florida beach Biological Conservation 110: 295-303.

Yasuda, T., Tanaka, H., Kittiwattanawong, K., Mitamura, H., Klom-in, W. and Arai, N. (2006). Do female green turtles (Chelonia mydus) exhibit reproductive seasonality in a year-round nesting rookery? Journal of Zoology 269: 451457. 